Игорь Иванович КАЛИГАНОВ 


\section{ПАИСИЙ ХИЛЕНДАРСКИЙ И ЕГО «ИСТОРИЯ СЛАВЯНОБОЛГАРСКАЯ» - МАНИФЕСТ НАЦИОНАЛЬНОГО ВОЗРОЖДЕНИЯ БОЛГАРСКОГО НАРОДА ${ }^{1}$}

\section{Аннотация:}

Статья посвящена Паисию Хилендарскому (1722-1773) и его «Истории славяноболгарской» - манифесту Национального возрождения болгарского народа. Этот афонский монах в 1762 г. сумел очертить главные задачи, которые стояли перед родным народом, находившимся под многовековым османским игом. Они заключались в восстановлении болгарской государственности, национальной церкви и создании системы национального просвещения - сети школ с преподаванием на болгарском языке. При этом он напоминал болгарам о существовании у них в древности мощного государства, появлении у них первого славянского царя по имени Симеон, а также наличии национальной церкви с собственным патриархом и славянскими книгами, которые широко распространились среди славян. «История» Паисия на протяжении почти столетия ходила в народе лишь в рукописном виде, но сыграла огромную роль в пробуждении болгарского национального самосознания.

\section{Ключевые слова:}

Болгария, национальное возрождение. «История славяноболгарская», программа, основные пункты, пробуждение народа.

Abstract: I.I. Kaliganov "Paisius of Hilendar and his "History of Slavo-Bulgarian": A MANIFESTO OF THE NATIONAL REVIVAL OF THE BULGARIANS".

The article is devoted to Paisius of Hilendar (1722-1773) and his "History of SlavoBulgarian": a manifesto of the national revival of the Bulgarians. This Athos monk in 1762 managed to outline the main tasks that faced his native people, who were under the centuries-old Ottoman yoke. These included the restoration of the Bulgarian state, the national Church, and the creation of a system of national education - a network of schools teaching in the Bulgarian language. At the same time, he reminded the Bulgarians of the existence of their powerful state in ancient times, the appearance of their first Slavic tsar named Simeon, as well as the presence of a national Church with its own Patriarch and Slavic books, which were widely distributed among the Slavs. For almost a century, Paisius "History" has been available only in handwritten form, but it has played a huge role in awakening the Bulgarian national identity.

\section{Keywords:}

Bulgaria, national revival. Slavo-Bulgarian history, the program, the main points, the awakening of the people.

\footnotetext{
1 Работа выполнена при финансовой поддержке РФФИ (грант № 18-512-76004).
} 
Паисий Хилендарский (1722-1773) - историограф, первый идеолог болгарского Национального возрождения, народный будитель. Точные сведения о вехах его жизненного пути отсутствуют. Считается, что он родился в западноболгарском г. Банско в семье зажиточных родителей. Светское его имя осталось неизвестным. По достижении 23 лет юноша отправился на Афон в Хилендарский (серб. вариант - Хиландарский) монастырь, где монашествовал его брат Лаврентий, ставший впоследствии игуменом. Другим его братом, по мнению ряда ученых, являлся хаджи Вылчо - богатый торговец из Банско. В Хилендаре юноша принял постриг под именем Паисий, сделавшись по истечении времени иеромонахом и помощником игумена. По предположению ученых, умер Паисий в 1773 г. в с. Амбелино, которое позднее вошло в г. Асеновград.

Пребывая на Святой Горе (главным образом в обителях Зограф и Хилендар), Паисий проникся мыслью о необходимости создания истории болгар, начавших забывать о своем славянском происхождении и героическом прошлом. В этом намерении, по собственному свидетельству Паисия, его укрепляли постоянные насмешки греческой и сербской афонской братии, укорявших болгар в незнании собственной истории и отсутствии у них трудов на эту тему. Некоторые ученые полагают, что на Паисия мог повлиять сербский историограф и просветитель Йован Раич (1726-1801), побывавший в Хиландаре в 1758 г. и составивший впоследствии в 60-е годы свою знаменитую «Историю разних словенских народов, наипаче Болгар, Хорватов и Сербов». Паисий мог зажечься идеей создания истории собственной истории болгар, имея для этого неплохие возможности. Испол-

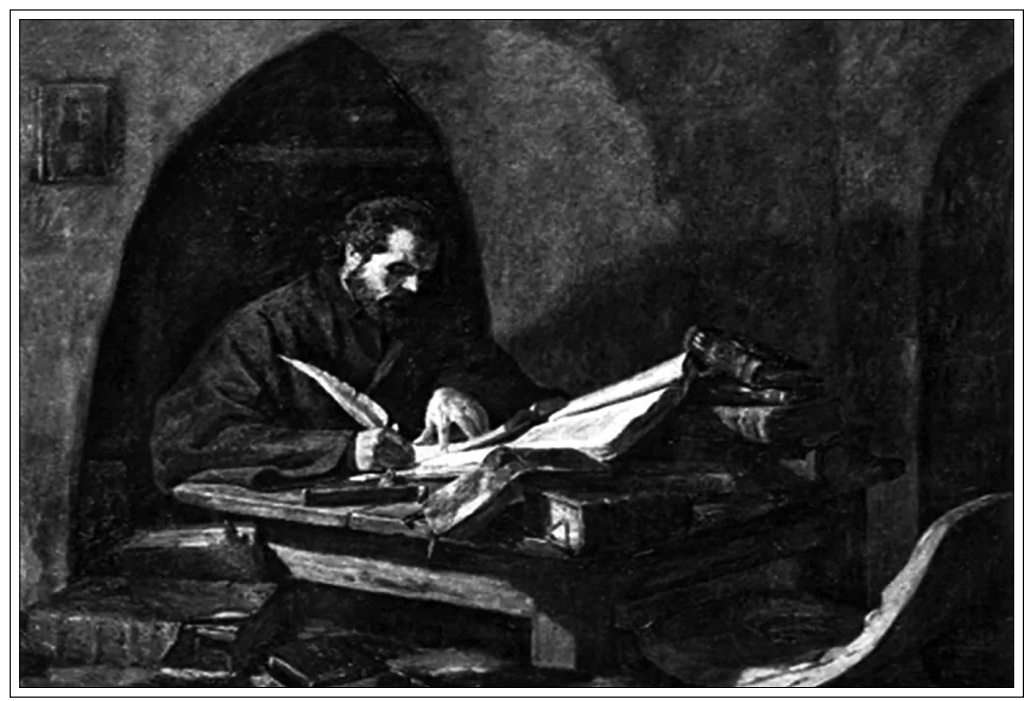

Паисий Хилендарский за работой.

Картина болгарского художника Кою Денчева 
няя обязанности «таксидиота» (т.е. сборщика пожертвований, которые скапливались в хилендарских подворьях на Балканах, и одновременно проводника групп паломников, отправлявшихся на Святую Гору), Паисий много передвигался, и это помогло ему начать целенаправленный сбор сведений об истории родного народа. Находясь в различных городах и монастырях, он выискивал такие сведения в древних рукописях, средневековых хрониках, русских печатных прологах и др. источниках.

Больше всего нужных данных он почерпнул в двух русских переводных книгах, обнаруженных им в библиотеке Сербской патриархии в Сремски-Карловцах. Это были переведенные по приказу Петра I труд римского кардинала Цезаря Барония «Деяния церковная и гражданская» (М., 1719) и сочинение далматинского историка Мавро Орбини «Книга Историография...» (СПб., 1722). Оригинальные произведения этих двух авторов (увидевшие свет на латинском и итальянском языках значительно раньше: соответственно Рим - 1588-1607 гг. и Пезар - 1601 г.) подверглись в русской версии существенной переработке и сокращению. Эти версии легли в основу эпохального сочинения Паисия «История славяноболгарская», работу над которым он завершил в 1762 г. Внешне способ составления истории Паисием напоминает приемы средневековых книжников: он постоянно прибегает к обильным компиляциям из чужих источников, чаще всего, не упоминая, откуда и что заимствуется. Он также предстает перед читателем в образе типичного средневекового автора с традиционными жалобами на телесные хвори, скудоумие и свою недостойность того дела, за которое взялся.

Свою «Историю» Паисий создавал в рукописном виде, не надеясь издать ее в какой-либо типографии по причине отсутствия таковых у болгар. Поэтому он страстно призывал болгарских читателей распространять его сочинение посредством переписывания, передавать из рук в руки, читать вслух публично. За вторую половину XVIII - первую половину XIX в. было создано несколько десятков списков паисиевской «Истории». В печатном виде целиком она вышла только через 123 года: сначала значительную ее часть издал Х. Павлович в его «Царственнике» (Будим, 1844), а затем уже целиком труд опубликовал А.В. Логинов (Люблин, 1885). В самой Болгарии она была отпечатана через 13 лет после логиновской публикации издателем М. Московым в Тырново в 1893 г. Несмотря на свой средневековый рукописный способ бытования, произведение Паисия приобрело для болгар силу настоящего воззвания и пробудило их от средневековой спячки. В нем было много принципиально нового: яркий страстный язык, который задевал читателей и слушателей за живое и заставлявлял их вспомнить о чувстве собственного национального достоинства,

В «Истории славяноболгарской» была начертана программа болгарского национального возрождения, ставившая задачей возрождение национального государства, национальной церкви и создание системы школ с преподаванием на национальном языке. Однако, для реализации этих, 
отчасти, позаимствованных у своих балканских соседей идей (например, идея ценности родного языка и его равенства или даже превосходства по отношению к другим, явно была воспринята им от хорватского просветителя А. Качича Миошича: «Приятная беседа народа славянского», 1756) требовались определенные социальные силы, которые в болгарских землях тогда отсутствовали. Паисий намного опередил свое время, поскольку первая средняя школа с преподаванием на национальном языке появилась в болгарских землях только через 73 года в 1835 г., национальная болгарская церковь в виде Болгарского экзархата была восстановлена через 108 лет в 1870 г., а возобновление болгарской государственности произошло через 116 лет: образование Княжества Болгария в 1878 г. после завершения русско-турецкой войны.

Подобный хронологический отрыв предначертаний Паисия создал ему в Болгарии ореол национального гения, и в целом с этим нельзя не согласиться. Но такое суждение не должно распространяться на завышенные оценки многих болгарских ученых, которые сравнивают этого народного будителя с Руссо, или даже Вольтером, и считают «Историю славяноболгарскую» начальной точкой отсчета Новой болгарской литературы. Если разделить последнее, окажется, что болгарская литература опередила в своем развитии русскую («новая» литература в России начинается с Пушкина), и Национальное возрождение началось в болгарском обществе раньше, чем у хорватов и сербов, которые находились по сравнению с болгарами в значительно более благоприятных условиях для развития своих национальных культур. Видимо, более научно корректным будет мнение о том, что «История славяноболгарская» есть начальная веха длительного «переходного» времени, первая точка отсчета в движении национальной словесности к Новой литературе.

Но нельзя отрицать факт того, что «История славяноболгарская», действительно, есть программа болгарского национального возрождения, хотя и с большим отложенным сроком реализации. В «Истории славяноболгарской», и в самом деле, есть еще много «старого», которое не способны целиком затушевать наслоения новаторской мысли Паисия. Автор призывает к использованию народного языка, но многие компилируемые им части произведения написаны на языке традиционной книжности, местами оно напоминает художественную публицистику, но это лишь крохотные «островки», затерянные в многочисленных не «новых» пассажах из книг Цезаря Барония и Мавро Орбини. Можно привести и много других подобных доводов. Поэтому характеристика «Истории славяноболгарской» как историографического и литературного памятника «переходного» периода представляется более объективной. Следует учитывать также то, что после паисиевской «Истории» в болгарской литературе в течение 43 лет наблюдается новаторская стагнация: качественно новые черты «переходного» периода проявляются в национальной словесности только в «Автобиографии» Софрония Врачанского (1805). 
Паисий Хилендарский считается в Болгарии одним из десяти самых известных национальных писателей. Его имя носит государственный университет в Пловдиве - втором по численности населения городе страны. В 1962 г. отца Паисия канонизировала в качестве святого Болгарская Православная церковь. Учрежденная в 2000 г. государственная премия им. Паисия Хилендарского (ею награждаются отечественные и зарубежные деятели культуры) является одной из самых престижных.

\section{ЛИТЕРАТУРА}

Арнаудов М. Паисий Хилендарский. Личност. Дело. Епоха. София, 1962. Велчев В. Паисий Хоилендарский. Епоха, личност, дело. София, 1987.

Калиганов И.И. Традиции старой письменности и возникновение новой болгарской литературы // Литература эпохи формирования наций в Центральной и Юго-Восточной Европе. Просвещение. Национальное возрождение. M., 1982.

Робинсон А.Н. Историография славянского Возрождения и Паисий Хилендарский. М., 1963.

Тодоров И. Паисий Хилендарский: Литература за живота и делото му. Аннотиран библиограф. указател. София, 2003.

Шишиланов И.Д. От Паисий до Раковски. София, 2004.

Matič T. Predgovor / A. Kačič Miośič. Razgowor ugodni naroda slovinskogo». Venecia, 1756.

\section{СПИСОК ИЛЛЮСТРАЦИЙ}

1. Афонский Хилендарский монастырь.

2. Болгарский Зографский монастырь на Афоне.

3. Отец Паисий за работой. Художник Кою Денчев.

4. Зографский список «Истории славяноболгарской». Автограф Паисия. 1762 г.

5. Памятник Паисию Хилендарскому в Софии.

6. Памятник Паисию Хилендарскому в г. Стрелча. Скульптор Спас Киричев.

7. Марка с изображением Паисия Хилендарского. 1929 г.

8. Банкнота номиналом 2 лева с изображением Паисия Хилендарского.

9. Памятная монета номиналом 2 лева с изображением Паисия Хилендарского. 2015 г. 